\title{
HOSSEUSIELLA AND REHMANNIELLA, TWO NEW GENERA IN THE TELOSCHISTACEAE
}

\author{
S. Y. Kondratyuk ${ }^{1 \#}$, P.-E. Persson ${ }^{2}$, M. Hansson ${ }^{2}$, L. Lókös ${ }^{3}$, D. Liu ${ }^{4}$, J.-S. Hur ${ }^{4}$ \\ I. KäRNEFELT $T^{5}$ and A. THELL ${ }^{5}$ \\ ${ }^{1}$ M. H. Kholodny Institute of Botany, Tereshchenkivska str. 2, 01004 Kiev, Ukraine; \\ ${ }^{\#}$ E-mail:ksya_net@ukr.net \\ ${ }^{2}$ Department of Biology, The Biology Building, Lund University, \\ Sölvegatan 35, 22362 Lund, Sweden; E-mails: pelle87@hotmail.com; mats.hansson@biol.lu.se \\ ${ }^{3}$ Department of Botany, Hungarian Natural History Museum, \\ H-1431 Budapest, Pf. 137, Hungary; E-mail: lokos.laszlo@nhmus.hu \\ ${ }^{4}$ Korean Lichen Research Institute, Sunchon National University, Sunchon 540-742, South Korea \\ ${ }^{5}$ Botanical Collections, Biological Museum, Lund University, Box 117, SE-221 00 Lund, Sweden; \\ E-mail: arne.thell@biol.lu.se
}

(Received 31 March, 2017; Accepted 10 December, 2017)

Two new genera in the subfamily Teloschistoideae (Teloschistaceae, Teloschistales) are described: Hosseusiella S. Y. Kondr., L. Lőkös et A. Thell for the Caloplaca chilensis group including three South American species and Rehmanniella S. Y. Kondr. et J.-S. Hur for the new species, R. wirthii S. Y. Kondr. from South Africa. The new genera are supported by a three-gene phylogeny based on ITS1/ITS2 nrDNA, 28S nrLSU, and 12S mtSSU sequences. The new taxonomic position of Elixjohnia ovis-atra in the subfamily Teloschistoideae is discussed. The two new species Hosseusiella gallowayiana and Rehmanniella wirthii are described, illustrated and compared with closely related taxa. Hosseusiella gallowayiana is recorded for the first time as the host for the lichenicolous fungus Arthonia tetraspora S. Y. Kondr. A key to the species of Hosseusiella is included, as well as new information of the related genus Follmannia. The following new combinations are proposed: Hosseusiella chilensis (Kärnefelt, S. Y. Kondr., Frödén et Arup) S. Y. Kondr., L. Lőkös, Kärnefelt et A. Thell, Hosseusiella pergracilis (Zahlbr.) S. Y. Kondr., L. Lőkös, Kärnefelt et A. Thell and Elixjohnia ovis-atra (Søchting, Søgaard et Sancho) S. Y. Kondr.

Key words: Elixjohnia, Follmannia, Hosseusiella, Hosseusiella gallowayiana, key, new genera, new species, phylogenetic analysis, Rehmanniella, Rehmanniella wirthii, South Africa, South America, Teloschistaceae, Teloschistoideae

\section{INTRODUCTION}

In the family Teloschistaceae subfamily Teloschistoideae several new genera have been recently described or resurrected, i.e. Josefpoeltia (Kondratyuk and Kärnefelt 1997); Follmannia, Haloplaca, Scutaria, Sirenophila, Teloschistopsis and others (Arup et al. 2013), Filsoniana, Fulgogasparrea, Kaernefia, Niorma (Kondratyuk et al. 2013), Tassiloa (Kondratyuk et al. 2015a), Elixjohnia, Harusavskia, Lasarenkoiopsis, Ikaeria, and Nevilleiella (Kondratyuk et al. 2017) 
(Table 2). In addition, many new species of the Teloschistoideae, discovered in the field or in herbaria, have been described by the senior author and colleagues. Molecular phylogeny of the subfamily Teloschistoideae has been discussed by Arup et al. (2013), Kondratyuk et al. (2013, 2015a, b, 2017) and Søchting et al. (2014). Two new genera, Hosseusiella and Rehmanniella, and two new species, Hosseusiella gallowayiana and Rehmanniella wirthii, are described as new to science in this study, supported by a phylogenetic analysis based on ITS1/ITS2 nrDNA, nrLSU and mtSSU sequences.

Following the description of the genera Hosseusiella and Rehmanniella and the new species Hosseusiella gallowayiana and Rehmanniella wirthii, the subfamily Teloschistoideae now comprises 25 genera and approximately 60 species, mainly distributed in the Southern Hemisphere. The Xanthorioideae with 39 genera and 180 species, the Caloplacoideae with 25 genera and approximately 120 species, occurs mainly in the Northern Hemisphere, while the Brownlielloideae with 11 genera and approximately 17 species, occurs mainly in the Southern Hemisphere.

\section{MATERIAL AND METHODS}

More than 1,000 specimens belonging to the family Teloschistaceae, collected between 2014-2017, deposited in the Korean Lichen Research Institute, Sunchon National University, South Korea (KoLRI), with duplicates in the Hungarian Natural History Museum (BP) and the Lichen Herbarium in the M. H. Kholodny Institute of Botany of National Academy of Sciences of Ukraine (KW-L), were hand-sectioned under a dissecting microscope (Nikon SMZ-645; Nikon, Tokyo, Japan) and examined using standard microscopical techniques. Anatomical characters were observed using a Nikon Eclipse E-200 microscope and a Zeiss Scope, complemented with a digital camera AxioCam ERc 5 s. Sections of apothecia were tested with water, K and KI (10\% potassium iodide).

Total DNA was extracted directly from the thalli according to Ekman (1999) and was purified with DNeasy Plant Mini Kit (QIAGEN, Germany). The nuclear ribosomal RNA gene region including the internal transcribed spacers 1 and 2 and the $5.8 \mathrm{~S}$ subunit (ITS) was amplified using the primers ITS1F (Gardes and Bruns 1993) and ITS4 (White et al. 1990), the 28S LSU using the primer LR5 (Vilgalys and Hester 1990), and the 12S $\mathrm{mtSSU}$ using the primers mtSSU1-mtSSU3R and mtSSU2R (Fedorenko et al. 2009, 2012).

The amplification was done using a Takara JP/TP600 PCR machine (Takara Bio Inc., Japan). One initial cycle of $5 \mathrm{~min}$ at $94{ }^{\circ} \mathrm{C}$ was followed by 30 cycles of the following steps: 30 seconds at $94{ }^{\circ} \mathrm{C}, 39$ seconds at $57^{\circ} \mathrm{C}$ and $1 \mathrm{~min}$ at $72{ }^{\circ} \mathrm{C}$. Amplifications were ended with a final cycle at $72{ }^{\circ} \mathrm{C}$ for 10 
min. PCR products were then sent to the sequencing facilities of the Genotech Cooperation, Seoul, South Korea, for cleaning and sequencing. The sequencing was carried out using the fluorescent marker BigDye and an ABI 3730xl sequencing machine (Applied Biosystems, Carlsbad, CA, USA).

DNA was extracted from the thalli according to Park et al. (2014), including the extra step for polysaccharide removal. A part of the nuclear ribosomal RNA gene region including the internal transcribed spacers (ITS) 1 and 2 and the $5.8 \mathrm{~S}$ subunit was amplified using the primers ITS4 and ITS5 (White et al. 1990). The PCR reactions were done in a Mastercycler pro (Eppendorf, Germany) PCR machine using the following program: $94{ }^{\circ} \mathrm{C}$ for $3 \mathrm{~min},\left(94{ }^{\circ} \mathrm{C}\right.$ for $45 \mathrm{~s}, 54{ }^{\circ} \mathrm{C}$ for $30 \mathrm{~s}, 72{ }^{\circ} \mathrm{C}$ for $\left.1 \mathrm{~min}\right) \times 30$ and $72{ }^{\circ} \mathrm{C}$ for $5 \mathrm{~min}$.

PCR products of good quality (as seen after agarose gel electrophoresis) were directly purified by Illustra ExoProStar 1-Step (GE Healthcare, UK) and sent for Sanger sequencing by Eurofins Genomics (Germany). In the case of an unspecific PCR product, the desired band was excised from the agarose gel and the DNA extracted using a Nucleospin PCR clean-up and Gel extraction kit from Macherey-Nagel (Germany) before being sent for sequencing, as previously described.

The consensus sequence was aligned with sequences from all related species retrieved from the GenBank database (Table 1). The consensus sequences were then deposited in GenBank under the accession numbers MG811841MG811854. Phylogenetic analysis was performed using the ITS region and $28 \mathrm{~S}$ nrLSU gene and $12 \mathrm{~S} \mathrm{mtSSU}$ sequences retrieved from the GenBank database and the 45 lichen-forming fungi investigated in this study. Sequence alignment was conducted in BioEdit and a phylogenetic tree was generated by the maximum parsimony (MP), minimum evolution (ME), and maximum likelihood (ML) analysis methods. Analyses were conducted using PAUP $4.0 \mathrm{~b} 10$ on a Macintosh platform (Swofford 2003), and in Mega 5.0 (Tamura et al. 2011) with the number of bootstrap trials set to 1,000.

The taxon sampling consists of 48 taxa of the Teloschistoideae (Fig. 3) with Brigantiaea ferruginea as outgroup (Table 1).

About 100 nrDNA and mtDNA sequences were submitted to GenBank for the 45 taxa.

\section{RESULTS}

\section{Phylogeny of the subfamily Teloschistoideae}

A phylogenetic tree of the subfamily Teloschistoideae is presented in Figure 1. All genera are represented by type species, but many specimens are included for the new genera. 
Table 1

Specimens included in the phylogenetic analysis with GenBank accession numbers. Newly submitted sequences are in bold

\begin{tabular}{|c|c|c|c|c|}
\hline Species name & Voucher details / references & ITS & LSU & $\mathrm{mtSSU}$ \\
\hline Brigantiaea ferruginea & SK779, Kondratyuk et al. (2013) & KF264622 & & KF264684 \\
\hline Brigantiaea ferruginea & SK780, Kondratyuk et al. (2013) & KF264623 & & KF264685 \\
\hline Brigantiaea ferruginea & $\begin{array}{l}\text { 121967, South Korea, Kondra- } \\
\text { tyuk et al. }(2017)\end{array}$ & KY614393 & & \\
\hline Brigantiaea ferruginea & $\begin{array}{l}\text { 121971, South Korea, Kondra- } \\
\text { tyuk et al. }(2017)\end{array}$ & KY614394 & & \\
\hline Brigantiaea ferruginea & $\begin{array}{l}\text { 121981, South Korea, Kondra- } \\
\text { tyuk et al. }(2017)\end{array}$ & KY614395 & & \\
\hline Elixjohnia bermaguiana & $\begin{array}{l}\text { SK979, Kondratyuk et al. (2013), } \\
\text { as Sirenophila bermaguiana }\end{array}$ & & & KF264706 \\
\hline Elixjohnia bermaguiana & $\begin{array}{l}\text { Type, Arup et al. (2013), as } \\
\text { Sirenophila bermaguiana }\end{array}$ & KC179299 & KC179245 & KC179584 \\
\hline Elixjohnia gallowayi & $\begin{array}{l}\text { isotype, Arup et al. (2013), as } \\
\text { Sirenophila gallowayi }\end{array}$ & KC179301 & KC179247 & KC179586 \\
\hline Elixjohnia jackelixii & $\begin{array}{l}\text { SK910, Kondratyuk et al. (2013), } \\
\text { as Sirenophila jackelixii }\end{array}$ & KF264655 & KF264683 & KF264707 \\
\hline Elixjohnia jackelixii & $\begin{array}{l}\text { SK911, Kondratyuk et al. (2013), } \\
\text { as Sirenophila jackelixii }\end{array}$ & & & KF264708 \\
\hline Elixjohnia jackelixii & $\begin{array}{l}\text { Arup et al. (2013), as Sirenophila } \\
\text { jackelixii }\end{array}$ & KC179303 & KC179248 & KC179587 \\
\hline Elixjohnia ovis-atra & $\begin{array}{l}\text { Arup et al. (2013), as Sirenophila } \\
\text { sp. } 20\end{array}$ & & KC179250 & KC179589 \\
\hline Elixjohnia ovis-atra & $\begin{array}{l}\text { Søchting et al. (2016), sub } \\
\text { Sirenophila ovis-atra }\end{array}$ & KU578083 & & \\
\hline Elixjohnia ovis-atra & $\begin{array}{l}\text { Søchting et al. (2016), sub } \\
\text { Sirenophila ovis-atra }\end{array}$ & KU578081 & & \\
\hline Elixjohnia ovis-atra & $\begin{array}{l}\text { Søchting et al. (2016), sub } \\
\text { Sirenophila ovis-atra }\end{array}$ & KU578078 & & \\
\hline Filsoniana australiensis & SK751, Kondratyuk et al. (2013) & KF264631 & KF264665 & KF264691 \\
\hline Follmannia orthoclada & Arup et al. (2013) & KC179291 & KC179191 & \\
\hline Follmannia orthoclada & $\begin{array}{l}\text { SK J76 = SKH94, Chile, } \\
\text { CL130446 KoLRI 020602, this } \\
\text { paper }\end{array}$ & MG811841 & & \\
\hline Follmannia orthoclada & $\begin{array}{l}\text { SK J78 = SKi00, Chile, } \\
\text { CL130446 KoLRI 020602, this } \\
\text { paper }\end{array}$ & MG811842 & & \\
\hline Follmannia orthoclada & $\begin{array}{l}\text { SK J79 = SKi01, Chile, } \\
\text { CL130446 KoLRI 020602, this } \\
\text { paper }\end{array}$ & MG811843 & & \\
\hline
\end{tabular}




\begin{tabular}{|c|c|c|c|c|}
\hline Species name & Voucher details / references & ITS & LSU & $\mathrm{mtSSU}$ \\
\hline Fominiella skii & Holotype, Vondrák et al. (2012) & HM582191 & & \\
\hline Fominiella skii & Vondrák et al. (2012) & HM582188 & & \\
\hline Fominiella skii & Vondrák et al. (2012) & HM582194 & & \\
\hline Fominiella skii & Vondrák et al. (2012) & HM582190 & & \\
\hline Fominiella tenerifensis & $\begin{array}{l}\text { SK D19, Spain, Kondratyuk et } \\
\text { al. (2017) }\end{array}$ & & KY614447 & KY614478 \\
\hline Fulgogasparrea appressa & Arup et al. (2013) & KC179332 & & \\
\hline Fulgogasparrea brouardii & Gaya et al. (2015) & KT291448 & KT291536 & \\
\hline Fulgogasparrea decipioides & SK689, Kondratyuk et al. (2013) & KF264644 & & KF264695 \\
\hline Fulgogasparrea decipioides & SK691, Kondratyuk et al. (2013) & KF264643 & & KF264694 \\
\hline Fulgogasparrea decipioides & Arup et al. (2013) & KC179333 & KC179269 & KC179608 \\
\hline Haloplaca sorediella & Arup et al. (2013) & KC179293 & & \\
\hline Haloplaca suaedae & Vondrák et al. (unpubl.) & HM582197 & & \\
\hline Harusavskia elenkinianoides & $\begin{array}{l}\text { SK 996, Chile, Kondratyuk et } \\
\text { al. (2017) }\end{array}$ & KY614403 & KY614451 & KY614484 \\
\hline Harusavskia elenkinianoides & $\begin{array}{l}\text { SK 997, Chile, Kondratyuk et } \\
\text { al. (2017) }\end{array}$ & KY614404 & KY614452 & KY614485 \\
\hline Harusavskia elenkinianoides & $\begin{array}{l}\text { SK 269, Chile, Kondratyuk et } \\
\text { al. (2017) }\end{array}$ & KY614405 & KY614453 & KY614486 \\
\hline Hosseusiella chilensis & Gaya et al. (2012) & JQ301660 & JQ301551 & JQ301485 \\
\hline Hosseusiella chilensis & $\begin{array}{l}\text { SK J43 = SK H65, Chile, CL } \\
130422 \text { KoLRI 020556, this } \\
\text { paper }\end{array}$ & MG811844 & & \\
\hline Hosseusiella chilensis & $\begin{array}{l}\text { SK J44 = SK H67, Chile, CL } \\
130418 \text { KoLRI 020552, this } \\
\text { paper }\end{array}$ & MG811845 & & \\
\hline $\begin{array}{l}\text { Hosseusiella gallowa- } \\
\text { yiana }\end{array}$ & $\begin{array}{l}\text { SK J46 = SK H78, Chile, CL } \\
130553 \text { KoLRI 020689, this } \\
\text { paper }\end{array}$ & MG811846 & & \\
\hline $\begin{array}{l}\text { Hosseusiella gallowa- } \\
\text { yiana }\end{array}$ & $\begin{array}{l}\text { SK J47 = SK H79, Chile, CL } \\
130553 \text { KoLRI 020689, this } \\
\text { paper }\end{array}$ & MG811847 & & \\
\hline $\begin{array}{l}\text { Hosseusiella gallowa- } \\
\text { yiana }\end{array}$ & $\begin{array}{l}\text { SK J71 = SK H80, Chile, CL } \\
130218 \text { KoLRI 017651, this } \\
\text { paper }\end{array}$ & MG811848 & & \\
\hline Hosseusiella pergracilis & $\begin{array}{l}\text { SK J48 = SK H87, Chile, CL } \\
130515 \text { KoLRI 020651, this } \\
\text { paper }\end{array}$ & MG811849 & & \\
\hline Hosseusiella pergracilis & $\begin{array}{l}\text { SK J72 = SK H90, Chile, CL } \\
\text { 130397 KoLRI 020531, this } \\
\text { paper }\end{array}$ & MG811850 & & \\
\hline
\end{tabular}




\begin{tabular}{|c|c|c|c|c|}
\hline Species name & Voucher details / references & ITS & LSU & $\mathrm{mtSSU}$ \\
\hline Ikaeria aurantiellina & $\begin{array}{l}\text { SK 538, Spain, Kondratyuk et } \\
\text { al. (2017) }\end{array}$ & KY614411 & & KY614490 \\
\hline Ikaeria aurantiellina & $\begin{array}{l}\text { SK 552, Spain, Kondratyuk et } \\
\text { al. (2017) }\end{array}$ & KY614412 & & KY614491 \\
\hline Ikaeria aurantiellina & $\begin{array}{l}\text { SK D29, Spain, Kondratyuk et } \\
\text { al. (2017) }\end{array}$ & KY614413 & & KY614492 \\
\hline Ikaeria aurantiellina & $\begin{array}{l}\text { SK D23, Spain, Kondratyuk et } \\
\text { al. (2017) }\end{array}$ & KY614414 & & KY614493 \\
\hline Josefpoeltia parva & Eichenberger et al. (unpubl.) & AM697883 & & \\
\hline Josefpoeltia sorediosa & SK991, Kondratyuk et al. (2013) & KF264645 & KF264673 & KF264696 \\
\hline Kaernefia kaernefeltii & SK921, Kondratyuk et al. (2013) & KF264652 & KF264680 & KF264703 \\
\hline $\begin{array}{l}\text { Lazarenkoella zoroasterio- } \\
\text { rum }\end{array}$ & $\begin{array}{l}\text { SK A45, Kondratyuk et al. } \\
(2015 b)\end{array}$ & KT456215 & KT456230 & KT456245 \\
\hline $\begin{array}{l}\text { Lazarenkoella zoroasterio- } \\
\text { rum }\end{array}$ & $\begin{array}{l}\text { SK A51, Kondratyuk et al. } \\
(2015 b)\end{array}$ & KT456216 & KT456231 & KT456246 \\
\hline $\begin{array}{l}\text { Lazarenkoella zoroasterio- } \\
\text { rum }\end{array}$ & $\begin{array}{l}\text { SK A55, Kondratyuk et al. } \\
(2015 b)\end{array}$ & KT456217 & KT456232 & KT456247 \\
\hline Lazarenkoiopsis ussuriensis & $\begin{array}{l}\text { SK A36, Russia, Kondratyuk et } \\
\text { al. (2017) }\end{array}$ & & & KY614497 \\
\hline Lazarenkoiopsis ussuriensis & $\begin{array}{l}\text { SK A37, Russia, Kondratyuk et } \\
\text { al. (2017) }\end{array}$ & KY614418 & KY614455 & KY614498 \\
\hline Lazarenkoiopsis ussuriensis & $\begin{array}{l}\text { SK D22, Russia, Kondratyuk et } \\
\text { al. (2017) }\end{array}$ & KY614419 & KY614456 & KY614499 \\
\hline Neobrownliella brownlieae & SK831, Kondratyuk et al. (2013) & KF264626 & KF264661 & KF264687 \\
\hline Neobrownliella brownlieae & SK838, Kondratyuk et al. (2013) & KF264627 & KF264662 & KF264688 \\
\hline Neobrownliella montisfracti & SK230, Kondratyuk et al. (2013) & KF264624 & KF264659 & \\
\hline Nevilleiella lateritia & $\begin{array}{l}\text { SK 878, Australia, Kondratyuk } \\
\text { et al. (2017) }\end{array}$ & KY614426 & KY614463 & KY614501 \\
\hline Nevilleiella lateritia & $\begin{array}{l}\text { SK 261, Australia, Kondratyuk } \\
\text { et al. (2017) }\end{array}$ & KY614427 & KY614464 & KY614502 \\
\hline Nevilleiella marchantii & $\begin{array}{l}\text { SK D18, Australia, Kondratyuk } \\
\text { et al. (2017) }\end{array}$ & KY614425 & KY614462 & KY614500 \\
\hline Niorma chrysophthalma & Eichenberger et al. (unpubl.) & AM292836 & & \\
\hline Niorma chrysophthalma & Gaya et al. (2012) & & JQ301576 & JQ301518 \\
\hline Niorma chrysophthalma & $\begin{array}{l}\text { SK 818, Australia, Kondratyuk } \\
\text { et al. (2013) }\end{array}$ & KF264654 & KF264682 & KF264705 \\
\hline Niorma hosseusiana & Arup et al. (2013) & КС179318 & & \\
\hline Niorma hypoglauca & Arup et al. (2013) & KC179319 & & \\
\hline Niorma sieberianus & Gaya et al. (2008) & EU639655 & & \\
\hline Rehmanniella wirthii & SK 243 , this paper & MG811851 & MG811852 & MG811853 \\
\hline Rehmanniella wirthii & SK 244, this paper & & & MG811854 \\
\hline Scutaria andina & Arup et al. (2013) & KC179298 & KC179242 & KC179581 \\
\hline
\end{tabular}




\begin{tabular}{|c|c|c|c|c|}
\hline Species name & Voucher details / references & ITS & LSU & mtSSU \\
\hline Sirenophila cliffwetmorei & $\begin{array}{l}\text { SK A93, Australia, Kondratyuk } \\
\text { et al. (2017) }\end{array}$ & KY614438 & KY614471 & KY614513 \\
\hline Sirenophila eos & SK912, Kondratyuk et al. (2013) & KF264656 & & \\
\hline Sirenophila eos & Arup et al. (2013) & KC179300 & KC179246 & KC179585 \\
\hline Sirenophila eos & Gaya et al. (2015) & KT291455 & KT291542 & KT291489 \\
\hline Sirenophila gintarasii & Arup et al. (2013) & KC179302 & & \\
\hline Sirenophila gintarasii & $\begin{array}{l}\text { SK D17, Australia, Kondratyuk } \\
\text { et al. (2017) }\end{array}$ & KY614437 & KY614470 & KY614512 \\
\hline Sirenophila maccarthyi & Arup et al. (2013) & KC179304 & КC179249 & KC179588 \\
\hline Stellarangia elegantissima & Arup et al. (2013) & KC179310 & KC179254 & KC179593 \\
\hline Stellarangia testudinea & Arup et al. (2013) & KC17912 & & \\
\hline Tassiloa digitaurea & $\begin{array}{l}\text { SK A34, Kondratyuk et al. } \\
(2015 a)\end{array}$ & KР096222 & & КР096224 \\
\hline Tassiloa wetmorei & Lumbsch et al. (2011) & HQ317923 & & \\
\hline Teloschistes flavicans & $\begin{array}{l}\text { FNM-139, Fedorenko et al. } \\
(2009,2012)\end{array}$ & EU681363 & & EU680955 \\
\hline Teloschistes flavicans & Arup et al. (2013) & KC179317 & KC179255 & KC179594 \\
\hline Teloschistes flavicans & $\begin{array}{l}\text { FNM-218, Fedorenko et al. } \\
(2009,2012)\end{array}$ & EU681362 & & JN984150 \\
\hline Teloschistes flavicans & Gaya et al. (2012) & & JQ301578 & \\
\hline Teloschistopsis bonae-spei & Arup et al. (2013) & KC179322 & KC179257 & KC179596 \\
\hline $\begin{array}{l}\text { Teloschistopsis chryso- } \\
\text { carpoides }\end{array}$ & Arup et al. (2013) & KC179323 & & \\
\hline Teloschistopsis eudoxa & Arup et al. (2013) & KC179324 & KC179258 & KC179597 \\
\hline Villophora isidioclada & Arup et al. (2013) & KC179325 & KC179266 & KC179606 \\
\hline Wetmoreana texana & SK537, Kondratyuk et al. (2013) & KF264657 & & KF264710 \\
\hline Wetmoreana texana & SK536, Kondratyuk et al. (2013) & KF264658 & & KF264711 \\
\hline Wetmoreana texana & Arup et al. (2013) & KC179337 & KC179273 & KC179612 \\
\hline
\end{tabular}

The subfamily Teloschistoideae is divided into 25 clades. Six groups can be discerned: the Teloschistes s. 1. group with 8 clades, the Follmannia s. 1. group with 4 clades, the Filsoniana s. 1. group with 3 clades, the SirenophilaLazarenkoiopsis group with 5 or 6 clades, and, finally, the genera Kaernefia and Stellarangia, positioned as sister groups to the Sirenophila-Lazarenkoiopsis clade (Fig. 1).

New clades, in particular, the recently proposed Ikaeria is positioned as a sister group to Yoshimuria in the Teloschistes s. l. group, Harusavskia and Nevilleiella are positioned in the Filsoniana s. 1. group, and Elixjohnia and Lazarenkoiopsis belong to the Sirenophila-Lazarenkoiopsis group (Fig. 1). 
Table 2

Genera of the subfamily Teloschistoideae confirmed by molecular phylogeny

Genus name Type species

Original generic

description / recent

treatment

1 Catenarina Søchting,

Catenarina desolata Søchting, Søgaard et

Søchting et al.

Søgaard, Arup, Elvebakk Elvebakk

(2014)

et Elix

2 Elixjohnia S. Y. Kondr. et J.-S. Hur

Elixjohnia jackelixii (S. Y. Kondr., Kärnefelt

et A. Thell) S. Y. Kondr. et J.-S. Hur

Kondratyuk et al. (2017)

3 Filsoniana S. Y. Kondr.,

Filsoniana australiensis (S. Y. Kondr.,

Kondratyuk et al.

Kärnefelt, Elix, A. Thell et

J.-S. Hur

Kärnefelt et Filson) S. Y. Kondr., Kärnefelt,

Elix, A. Thell, J. Kim, A. S. Kondratyuk et J.-S. Hur

4 Follmannia C. W. Dodge

Follmannia rufa C. W. Dodge [current name

F. orthoclada (Zahlbr.) Frödén, Arup et

Søchting]

5 Fulgogasparrea S. Y.

Fulgogasparrea decipioides (Arup) S. Y.

Kondr., N.-H. Jeong,

Kondr., Kärnefelt, Elix, A. Thell, M.-H.

Kärnefelt, Elix, A. Thell et Jeong et J.-S. Hur

J.-S. Hur

6 Gintarasiella S. Y. Kondr. et J.-S. Hur

Gintarasiella aggregata (Kantvilas et S. Y.

Kondr.) S. Y. Kondr. et J.-S. Hur

(2013)

Arup et al. (2013)

7 Haloplaca Arup, Søchting et Frödén

Haloplaca britannica (R. Sant.) Arup, Frödén et Søchting

8 Harusavskia S. Y. Kondr.

Harusavskia elenkinianoides S. Y. Kondr., X. Y. Wang, S.-O. Oh et J.-S. Hur

Kondratyuk et al. (2013)

Kondratyuk et al. (2017)

Arup et al. (2013)

Kondratyuk et al.

9 Hosseusiella S. Y. Kondr., L. Lőkös et A. Thell

Hosseusiella chilensis (Kärnefelt, S. Y.

Kondr., Frödén et Arup) S. Y. Kondr., L.

Lőkös et A. Thell

10 Josefpoeltia S. Y. Kondr. et Kärnefelt

Josefpoeltia boliviensis S. Y. Kondr. et

this paper

Kärnefelt [current name J. parva (Räsänen) Frödén et L. Lindblom]

11 Ikaeria S. Y. Kondr., D. Upreti et J.-S. Hur

Ikaeria aurantiellina (Harm.) S. Y. Kondr., D. Upreti et J.-S. Hur

Kondratyuk and

Kärnefelt (1997)

12 Kaernefia S. Y. Kondr., Elix, A. Thell et J.-S. Hur

13 Lazarenkoiopsis S. Y. Kondr., L. Lőkös et J.-S. Hur

Kaernefia kaernefeltii (S. Y. Kondr., Elix et A. Thell) S. Y. Kondr., Elix, A. Thell, J. Kim, A.

S. Kondratyuk et J.-S. Hur

Lazarenkoiopsis ussuriensis (Oxner, S. Y.

Kondr. et Elix) S. Y. Kondr., L. Lőkös et J.-S. Hur

Neobrownliella brownlieae (S. Y. Kondr., Elix et Kärnefelt) S. Y. Kondr., Elix, Kärnefelt et A. Thell

Kondr., Elix, Kärnefelt et A. Thell

Nevilleiella marchantii (S. Y. Kondr. et

Kärnefelt) S. Y. Kondr. et J.-S. Hur

Kondratyuk et al. (2017)

Kondratyuk et al. (2013)

Kondratyuk et al. (2017)

Kondratyuk et al. (2015b)

Kondratyuk et al. (2017) 


\begin{tabular}{|c|c|c|c|}
\hline & Genus name & Type species & $\begin{array}{l}\text { Original generic } \\
\text { description /recent } \\
\text { treatment }\end{array}$ \\
\hline 16 & Niorma A. Massal. & $\begin{array}{l}\text { Niorma hypoglauca (Nyl.) S. Y. Kondr., } \\
\text { Kärnefelt, Elix, A. Thell, M. H. Jeong et J.-S. } \\
\text { Hur }\end{array}$ & $\begin{array}{l}\text { Kondratyuk et al. } \\
\text { (2013) }\end{array}$ \\
\hline 17 & $\begin{array}{l}\text { Rehmanniella S. Y. Kondr. } \\
\text { et J.-S. Hur }\end{array}$ & Rehmanniella wirthii S. Y. Kondr. & this paper \\
\hline 18 & $\begin{array}{l}\text { Scutaria Søchting, Arup et } \\
\text { Frödén }\end{array}$ & $\begin{array}{l}\text { Scutaria andina (Räsänen) Søchting, Frödén } \\
\text { et Arup }\end{array}$ & Arup et al. (2013) \\
\hline 19 & $\begin{array}{l}\text { Sirenophila Søchting, } \\
\text { Arup et Frödén }\end{array}$ & $\begin{array}{l}\text { Sirenophila gintarasii (S. Y. Kondr. et } \\
\text { Kärnefelt) Arup, Frödén et Søchting }\end{array}$ & Arup et al. (2013) \\
\hline 20 & $\begin{array}{l}\text { Stellarangia Frödén, Arup } \\
\text { et Søchting }\end{array}$ & $\begin{array}{l}\text { Stellarangia elegantissima (Nyl.) Frödén, } \\
\text { Arup et Søchting }\end{array}$ & Arup et al. (2013) \\
\hline 21 & $\begin{array}{l}\text { Tassiloa S. Y. Kondr., } \\
\text { Kärnefelt, A. Thell, Elix et } \\
\text { J.-S. Hur }\end{array}$ & $\begin{array}{l}\text { Tassiloa digitaurea (Søgaard, Søchting et } \\
\text { Sancho) S. Y. Kondr., Kärnefelt, A. Thell, J. } \\
\text { Kim, A. S. Kondratiuk et J.-S. Hur }\end{array}$ & $\begin{array}{l}\text { Kondratyuk et al. } \\
(2015 a)\end{array}$ \\
\hline 22 & Teloschistes Norman & Teloschistes flavicans (Sw.) Norman & $\begin{array}{l}\text { Kondratyuk et al. } \\
\text { (2013) }\end{array}$ \\
\hline 23 & $\begin{array}{l}\text { Teloschistopsis Frödén, } \\
\text { Søchting et Arup }\end{array}$ & $\begin{array}{l}\text { Teloschistopsis chrysocarpoides (Vain.) Frö- } \\
\text { dén, Arup et Søchting }\end{array}$ & Arup et al. (2013) \\
\hline 24 & $\begin{array}{l}\text { Villophora Søchting, Arup } \\
\text { et Frödén }\end{array}$ & $\begin{array}{l}\text { Villophora isidioclada (Zahlbr.) Søchting, } \\
\text { Frödén et Arup }\end{array}$ & Arup et al. (2013) \\
\hline 25 & $\begin{array}{l}\text { Wetmoreana Arup, Søcht- } \\
\text { ing et Frödén }\end{array}$ & $\begin{array}{l}\text { Wetmoreana texana (Wetmore et Kärnefelt) } \\
\text { Arup, Søchting et Frödén }\end{array}$ & Arup et al. (2013) \\
\hline
\end{tabular}

In the combined phylogenetic analysis, based on ITS1/ITS2 nrDNA, $28 \mathrm{~S}$ nrLSU, and $12 \mathrm{~S} \mathrm{mtSSU}$ sequences, the new genus Hosseusiella, comprising three species, H. chilensis, H. gallowayiana and H. pergracilis, bears a sister position to the South American Follmannia. However, the joint support of Follmannia and Hosseusiella together is rather low, but Hosseusiella alone is strongly supported (Fig. 1, Table 2).

The phylogenetic tree of the subfamily Teloschistoideae based exclusively on ITS-sequences also includes species of Tarasginia and Raesaeneniana from the subfamily Brownlielloideae.

Hosseusiella S. Y. Kondr., L. Lőkös, Kärnefelt et A. Thell, gen. nov. MycoBank no.: MB 824004.

Similar to Follmannia, but differs in having a regular, rosette-like thallus forming convex isidious tufts, in having better developed, convex, regularly radiating lobes and finger-like isidia, in having "textura intricata" plectenchyma in the cortical layer and in the true exciple, and in having shorter ascospores and shorter conidia. 


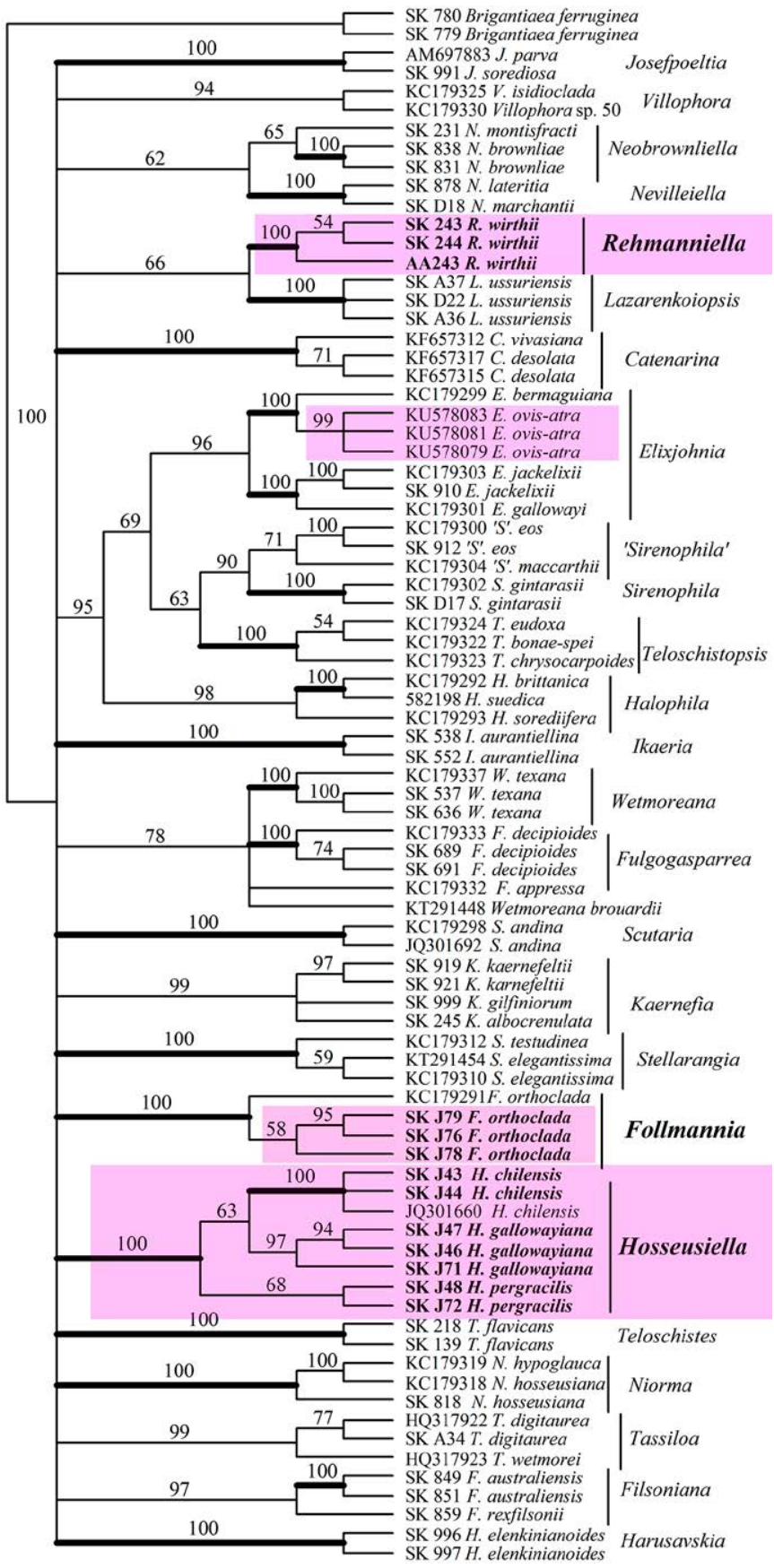

Fig. 1. Phylogenetic tree of the members of the subfamily Teloschistoideae after ITS1/ITS2 data set 
Type species: Hosseusiella chilensis (Kärnefelt, S. Y. Kondr., Frödén et Arup) S. Y. Kondr., L. Lőkös, Kärnefelt et A. Thell.

Thallus small, crustose to foliose forming well-developed rosettes with well-developed lobes in the peripheral zone, or microfruticose forming bulky cushions in the centre; yellowish red or brownish orange to dark reddish orange or orange yellow, usually paler, yellow to yellowish orange at terminal portions of the lobes or tips of isidia, surface shiny or matt; isidiate or with numerous isidia forming convex tufts; in one species the centre is covered by apothecia or verrucules from apothecial initials. Thalline lobes well developed, regularly radiating, rather narrow and convex, irregularly branched closely adpressed to the substrate or lax to ascending and terete; without or with numerous isidia, forming convex tufts of an isidious mass; attached to substrate by medullary hyphae, lower cortex absent or present, where lobes lift from the substrate.

Apothecia numerous to rare, stipitate, lecanorine, biatorine or zeorine, disc concave or plane, orange to reddish or brownish orange; margin yellowish orange; true exciple of textura intricata; asci 8-spored; ascospores hyaline, bipolar, narrowly ellipsoid. Conidia narrowly bacilliform.

Chemistry: Thallus and apothecia contain parietin, teloschistin, fallacinal, parietinic acid and emodin.

Ecology: Hosseusiella chilensis is mainly an epiphytic taxon growing on bark of both dead and living twigs or branches of various shrubs, trees and cacti, always sun exposed (often in open, preferably grazed, shrub vegetation, from about 25 to $1100 \mathrm{~m}$ a.s.l.), whereas $H$. gallowayiana and H. pergracilis are epilithic lichens growing on siliceous rocks from the coastal zone to low altitudes in lowlands and mountains.

Etymology: Named in honour of the German botanist Carl Curt Hosseus (1878-1950) professor in botany at the University of Córdoba, Argentina (1916-1946) and director of the Botanical Museum. He collected extensively in South America, and published numerous papers on bamboo canes, conifers, cacti and mosses of South America and Argentina in particular.

Species diversity and distribution: The genus is composed of three species, rather common in southern part of the South American continent.

Taxonomic notes: As mentioned in the original description of Caloplaca chilensis Kärnefelt, S. Y. Kondr., Frödén et Arup, the morphology of this species was intermediate between that of Caloplaca and Xanthoria. Moreover, ITS sequences showed no similarity with either Xanthoria or closely related placodioid species. The authors concluded that "the DNA data clearly showed that "Caloplaca" chilensis belonged to Caloplaca as then defined, but no closely related species could be identified" (Kärnefelt et al. 2002).

Futher molecular data for Hosseusiella chilensis (as Caloplaca chilensis) were submitted to GenBank and published by Gaya et al. $(2012,2015)$. From a consideration of the data for Follmannia orthoclada and Hosseusiella chilensis it was 
concluded, that "Caloplaca" chilensis may be a member of the Follmannia clade without bootstrap support. With the inclusion of additional specimens, species and molecular markers in the present study, Hosseusiella and Follmannia are supported as separate genera (Fig. 1).

Hosseusiella is morphologically similar to Follmannia, but differs in forming regular, rosette-like thallus to convex isidiose tufts, in having better developed, very convex, regularly radiating lobes and finger-like isidia, in having "textura intricata" plectenchyma in the cortical layer and in the true exciple where hyphae with 5-15 $\mu \mathrm{m}$ long and 1.5-2 $\mu \mathrm{m}$ thick lumina are observed. In addition, the ascospores and conidia are shorter in Hosseusiella.

Hosseusiella and Harusavskia both form rosette-like thalli, but Hosseusiella differs in having ascospores without a halo.

Hosseusiella differs from the similar Teuvoahtiana by the lack of rosette-like thallus, as well as in having "textura intricata" plectenchyma in the cortical layer of thallus.

Key to the species of Hosseusiella

1a Thallus corticolous; with numerous apothecia in the centre, isidia absent

H. chilensis

$1 \mathrm{~b}$ Thallus saxicolous; thallus with numerous isidia, apothecia rather rare or poorly developed

2a Isidia large, $0.2-0.3(-0.35) \mathrm{mm}$ diam. and to $0.5-1.5(-2) \mathrm{mm}$ long, branched, differentiated from ascending overlapping thalline lobes; thallus visibly crustose, flat, forming large confluent aggregations without distinct lobes, with minute wart-like finger-like isidia or microfruticose, forming bulky formations due to numerous ascending and densely overlapping thalline lobes and isidia; [thalline lobes $0.1-0.25 \mathrm{~mm}$ wide (Zahlbruckner 1925)]

H. pergracilis

2b Isidia small, 60-100 $\mu \mathrm{m}$ diam. and to 60-100(-150) $\mu \mathrm{m}$ long, much broader and usually paler of thalline lobes, pure yellow; thallus regularly rounded, rosette-like; thalline lobes $0.2-0.7 \mathrm{~mm}$ wide $\quad H$. gallowayiana

Hosseusiella chilensis (Kärnefelt, S. Y. Kondr., Frödén et Arup) S. Y. Kondr., L. Lőkös, Kärnefelt et A. Thell, comb. nova

MycoBank no.: MB 824007.

Basionym: Caloplaca chilensis Kärnefelt, S. Y. Kondr., Frödén et Arup, in Kärnefelt et al., The Bryologist 105: 302 (2002). 


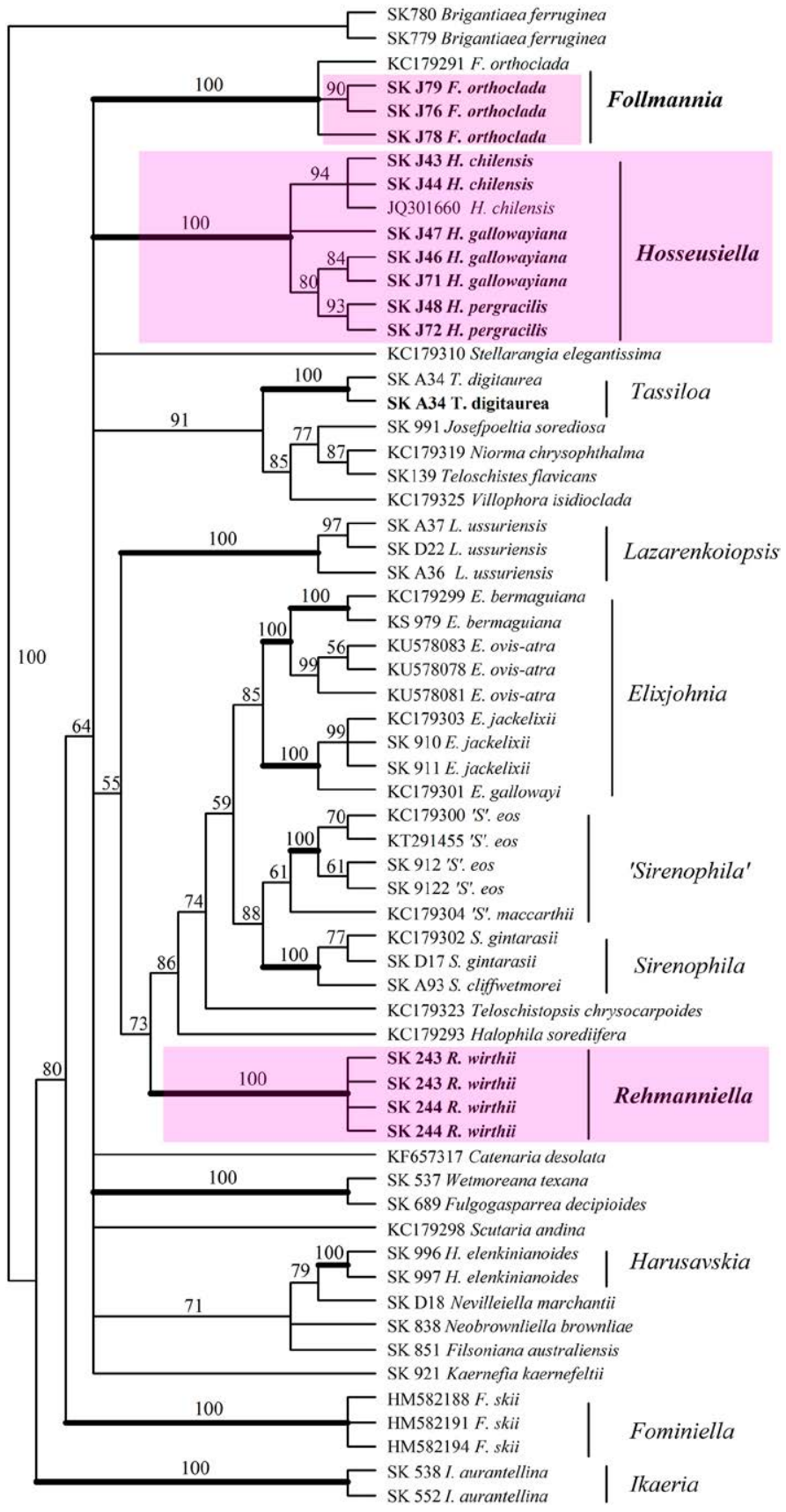

Fig. 2. Phylogenetic tree of the members of the subfamily Teloschistoideae after combined data set based on ITS1/ITS2 nr DNA, 28S nrLSU and 12S mtSSU sequences 
For a detailed description see Kärnefelt et al. (2002).

Specimens of Hosseusiella chilensis examined: Chile, La Serena, Fray Jorge National Park, on branches of tree, Hosseusiella chilensis damaged by Arthonia tetraspora in parts. Lat.: $30^{\circ} 37^{\prime} 32.4^{\prime \prime}$ S; Long.: 71 39' 45.7" W; Alt.: ca. $279 \mathrm{~m}$ a.s.l. Coll.: Oh, S.-O., Hur, J.-S., 15.11.2013 (CL130418) (KoLRI 020552 voucher for DNA SK H67 = J44); the same locality (CL130422) (KoLRI 020556 voucher for DNA SK H65 = J43); the same locality (CL130545) (KoLRI 020681).

Hosseusiella gallowayiana S. Y. Kondr., L. Lőkös, J.-S. Hur, Kärnefelt et A. Thell, spec. nova

(Figs 3-4)

MycoBank no.: MB 824009.

Similar to Hosseusiella pergracilis, but differs in having a microfruticose thallus, consisting of bulky cushions formed by numerous ascending and densely overlapping thalline lobes hardly differentiated from isidia, as well as in having rare apothecia.

Type: Chile, La Serena, on rock, Hosseusiella gallowayiana damaged by Arthonia tetra-

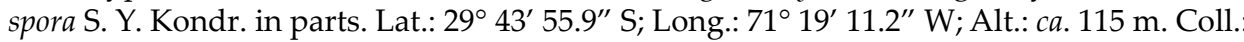
Oh, S.-O., Hur, J.-S., 12.11.2013 (CL130361) (KoLRI 020494 - holotype); the same locality, CL130362 (KoLRI 020495 - isotype).

Thallus 0.5-2(-3) cm wide but forming larger aggregations, microfruticose with narrowly attached, overlapping thalline lobes or isidia-like structures in the central portion of the thallus, ascending towards the peripheral portion; deep reddish orange, brownish orange to dull brownish orange in the centre, becoming paler yellowish towards the lobe tips. Thalline lobes, ascending and terete in the centre, lobes $0.1-0.3 \mathrm{~mm}$ wide in middle portions to $0.2-0.5(-0.7) \mathrm{mm}$ wide towards the tips, in section from ovoid to elongated, $0.2-0.3 \times 0.3-0.7 \mathrm{~mm}$ or $0.2-0.7 \mathrm{~mm}$ wide; in section cortical layer (10-)20-50($80[-100]) \mu \mathrm{m}$ thick, irregularly developed on all sides of terete thalline lobes, prosoplectenchymatous, hyphae with lumina $c a .1-1.5(-2) \mu \mathrm{m}$ diam. orientated longitudinally; algal cells (7-)12-16(-17) $\mu \mathrm{m}$ with yellow oil droplets of 1-3 $\mu \mathrm{m}$ diam., aggregated in clusters (30-)50-100 $\mu \mathrm{m}$ across; medulla with distinct scleroplectenchymatous or prosoplectenchymatous tissue of 15-20(-30) $\mu \mathrm{m}$ diam.; isidia $0.2-0.3(-0.35) \mathrm{mm}$ diam. and $0.5-1.5(-2) \mathrm{mm}$ long, branched.

Apothecia rare, terminal at the tips of lobes, $0.5 \mathrm{~mm}$ diam., $0.3 \mathrm{~mm}$ thick in section, biatorine to zeorine; thalline margin with numerous isidia, concolorous with central part of thallus, dull orange or brownish orange; in section thalline exciple 50-120 $\mu \mathrm{m}$ thick, cortical layer developed irregularly, if present to $30 \mu \mathrm{m}$ thick with more conglutinated upper portion to $10(-15) \mu \mathrm{m}$ 
thick and "textura intricata" below; true exciple 30-60(-100) $\mu \mathrm{m}$ wide in the uppermost lateral portion with outermost layer to 10-15 $\mu \mathrm{m}$ thick of palisade plectenchyma, 20-30 $\mu \mathrm{m}$ thick in lower lateral and basal portions, algal zone with clusters of algal cells only in lower portion observed to $60 \mu \mathrm{m}$ diam., rounded or in irregular continuous, algal cells 7-12 $\mu \mathrm{m}$ diam., with yellow oil droplets; hymenium to $90 \mu \mathrm{m}$ high; epihymenium 15-20 $\mu \mathrm{m}$ thick, brownish yellow; asci 8-spored, simple and bipolar ascospores observed in the same asci; ascospores narrowly ellipsoid, cylindrical or fusiform, attenuated towards the tips, one cell sometimes somewhat longer, 10-13(-17) $\times 4-5(-6) \mu \mathrm{m}$ in water and 9-13(-14) $\times(4-) 5.5-7 \mu \mathrm{m}$ in $\mathrm{K}$; ascospore septum (2-)3-4.5(-8) $\mu \mathrm{m}$ wide in water and (3-)4-6(-7) $\mu \mathrm{m}$ wide in $\mathrm{K}$. Conidiomata rare, conidia small, bacilliform, (2-)2.5-3.2(-3.5) ×0.8-1.2 $\mu \mathrm{m}$.

Spot tests: Cortical layer of thalline exciple, uppermost portion of true exciple and epihymenium $\mathrm{K}+$ purple.

Ecology: It grows on rocks from coastal zone to localities of low altitudes. Hosseusiella gallowayiana is recorded as the host for Arthonia tetraspora S. Y. Kondr. for the first time.
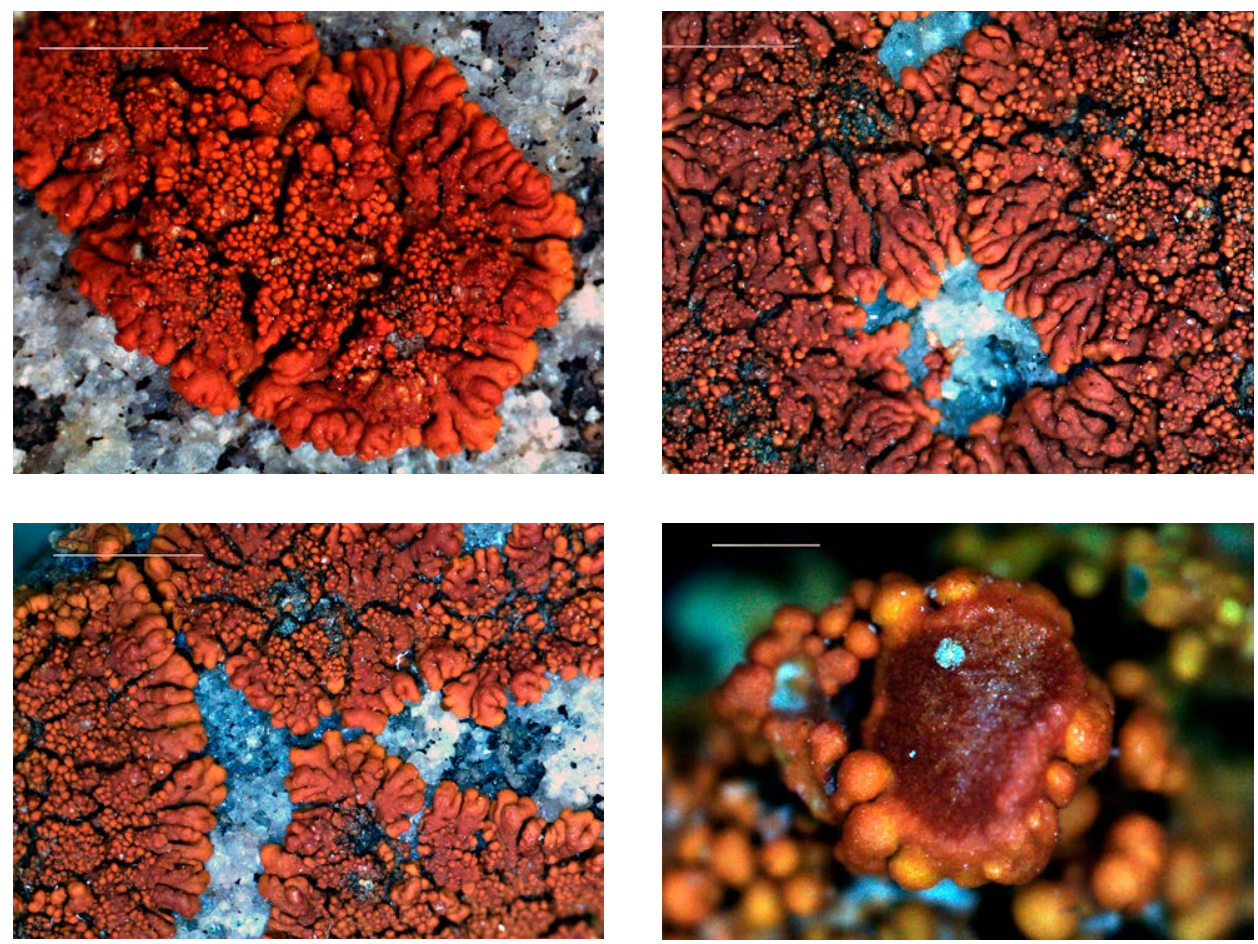

Fig. 3. Hosseusiella gallowayiana (CL130533), general habit (scale $1 \mathrm{~mm}$ ), and enlarged apothecia (bottom right, scale $0.5 \mathrm{~mm}$ ) 
Etymology: The species is named after David John Galloway (1942-2014) in recognition of his many contributions to the Southern Hemisphere lichens.

Distribution: Known from scattered localities in Chile, South America.

Taxonomic notes: The species is characterised by terete lobes with different modes of attachment to the substrate, at first closely attached, later rather lax, erect and overlapping.

Hosseusiella gallowayiana and $H$. chilensis have similar anatomical characters and distribution, as well as the same parasite Arthonia tetraspora. However, the new species differs in having a more bulky, thick and semiconvex thallus, due to numerous isidia and ascending terete thalline lobes in the centre of the thallus.

Hosseusiella gallowayiana is also similar to $H$. pergracilis, a rare South American isidiate species (Zahlbruckner 1925). The latter, however, differs in having an obviously crustose, flat thalli forming large confluent aggregations or microfruticose bulky cushions with numerous ascending and densely overlapping lobes, larger, hardly differentiated thalli without apothecia and conidiomata (Zahlbruckner 1925).
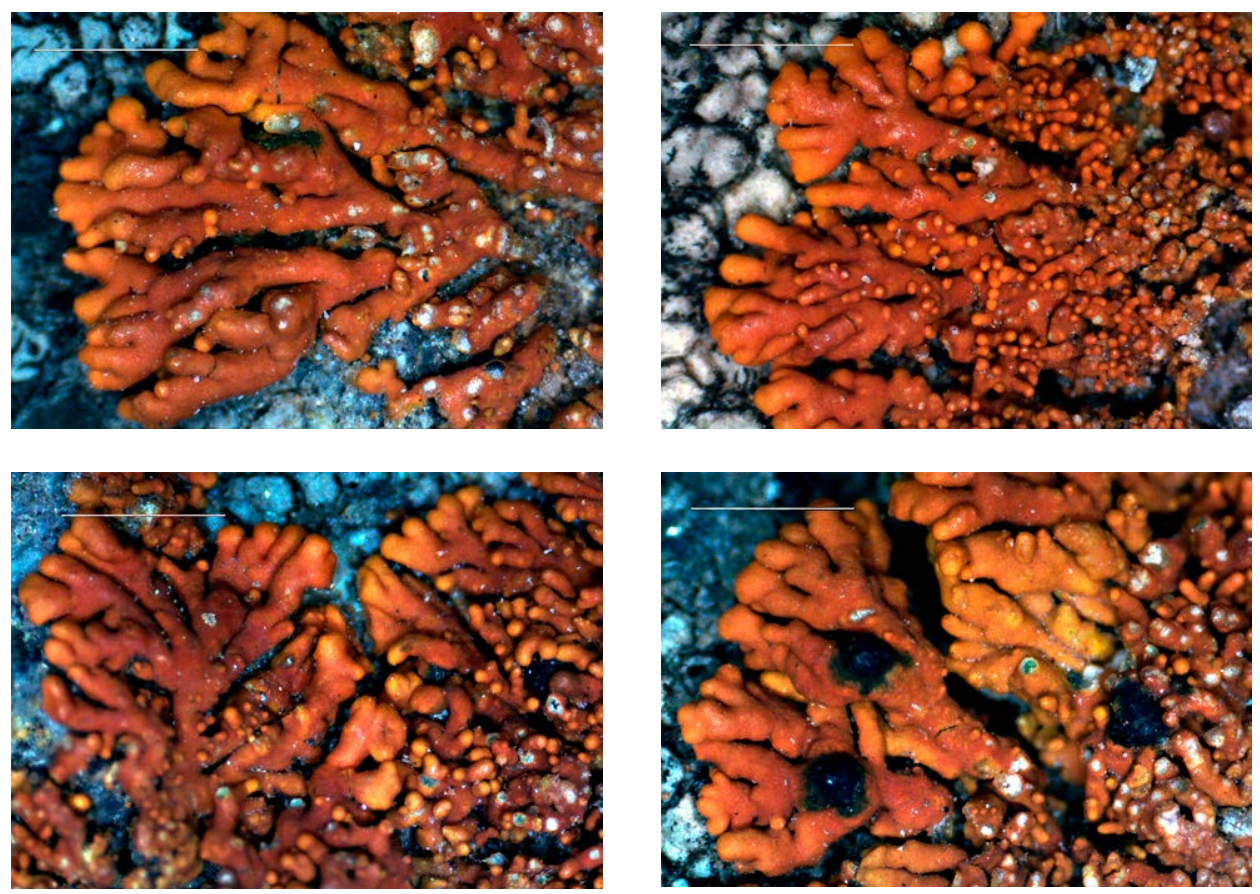

Fig. 4. Hosseusiella gallowayiana (CL130361, holotype), enlarged thalline lobes with isidia and with lichenicolous fungus Arthonia tetraspora (bottom right; scale $1 \mathrm{~mm}$ ) 
The rounded and regularly rosette-like thalli of Hosseusiella gallowayiana are reminiscent of both Austroplaca lucens (Nyl.) Søchting, Frödén et Arup and Rusavskia elegans (Link) S. Y. Kondr. et Kärnefelt, two species that differ from Hosseusiella gallowayiana in lacking isidia, while Zeroviella papillifera (Vain.) S. Y. Kondr. et J.-S. Hur is distinguished by scarce and scattered isidia. All of these taxa differ from $H$. gallowayiana in having paraplectenchymatous cortical layers and scleroplectenchymatous true exciples (Kondratyuk 2004, Kondratyuk et al. 2015c).

Follmannia orthoclada (Zahlbr.) Frödén, Arup et Søchting has similar morphology, but differs in having irregularly developed, separate, convex, shiny lobes, an intricately prosoplectenchymatous cortex with a thick epicortex (Arup et al. 2013).

Both "Caloplaca” malmeana Zahlbr. (= Callopisma brachysporum Malme 1926, non Caloplaca brachyspora Mereschk. 1913) and "Caloplaca" dissimilis (Malme) Zahlbr. (= Callopisma dissimile Malme) occur in South America, but differ in having squamulose thalli with much smaller thalline areoles, in lobulate, crenulate isidia, which become sorediose, in having a hypothallus, as well as shorter and wider ascospores (Malme 1926).

Specimens CL130361 (holotype) and CL130553 of Hosseusiella gallowayiana are damaged by Arthonia tetraspora S. Y. Kondr., a parasitic fungus originally described on $H$. chilensis (Kärnefelt et al. 2002).

Additional specimens of Hosseusiella gallowayiana examined: Chile, La Serena, Fray Jorge National Park, on rock, Hosseusiella gallowayiana damaged by Arthonia tetraspora S. Y. Kondr. in parts. Lat.: 30 37' 32.4" S; Long.: 71 39' 45.7' W; Alt.: ca. 279 m a.s.l. Coll.: Oh, S.-O., Hur, J.-S., 15.11.2013 [site 10] (CL130553) (KoLRI 020689 voucher for DNA SK H79 = J47, SK H78 = J46). - Chile, Patagonia, Torres del Paine, Y200 30 km, on rock. Lat.: 51 $22^{\prime}$ 36.4" S; Long.: 72 $45^{\prime}$ 18.8” W; Alt.: ca. $38 \mathrm{~m}$ a.s.l. Coll.: Oh, S.-O., Hur, J.-S., 19.01.2013 [site 7] (CL130218) (KoLRI 017651 voucher for DNA SK H80 = J71).

Hosseusiella pergracilis (Zahlbr.) S. Y. Kondr., L. Lőkös et A. Thell, comb. nova

(Figs 5-6)

MycoBank no.: MB 824012.

Basionym: Caloplaca pergracilis Zahlbr., Medd. Göteb. Bot. Trädg. 2: 20 (1925). Synonym: Gasparrinia pergracilis (Zahlbr.) Follmann, Nova Hedwigia 14: 265 (1967).

Specimens of Hosseusiella pergracilis examined: Chile, Caleta Tototal Baja, on rock. Lat.: $28^{\circ} 17^{\prime}$ 15.7" S; Long.: 71 10' 37.6" W; Alt.: ca. $203 \mathrm{~m}$ a.s.l. Coll.: Oh, S.-O., Hur, J.-S., 14.11.2013 [site 09] (CL130515) (KoLRI 020651 voucher for DNA SK H87 = J48). - Chile, La Higuera, Caleta De Hornos, on rock. Lat.: 29 38' 29.1" S; Long.: 71 17' 54.9” W; Alt.: ca. 110 $\mathrm{m}$ a.s.l. Coll.: Oh, S.-O., Hur, J.-S., 14.11.2013 [site 03] (CL130397) (KoLRI 020531 voucher for DNA SK H90 = J72). 

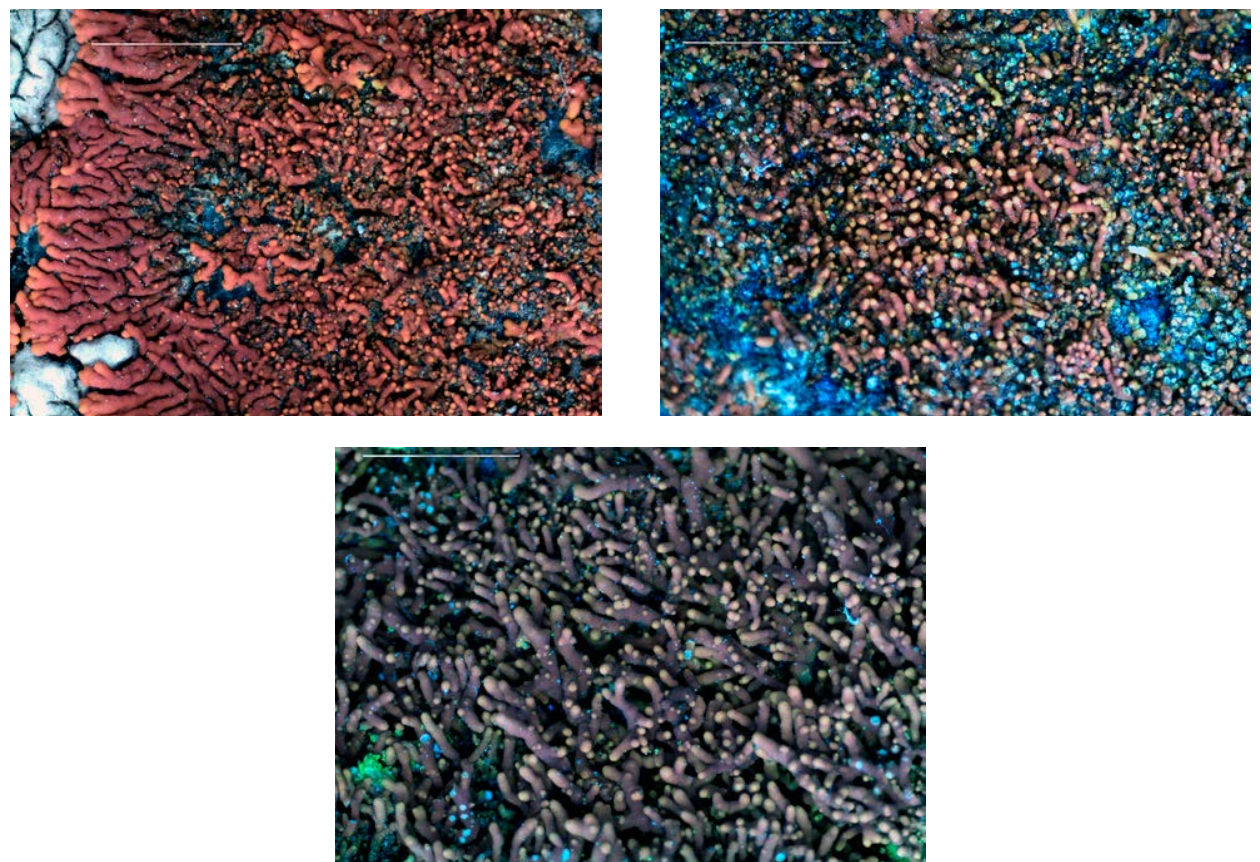

Fig. 5. Hosseusiella pergracilis (CL130397), general habit. Scale $2 \mathrm{~mm}$ (top) and $1 \mathrm{~mm}$ (bottom)
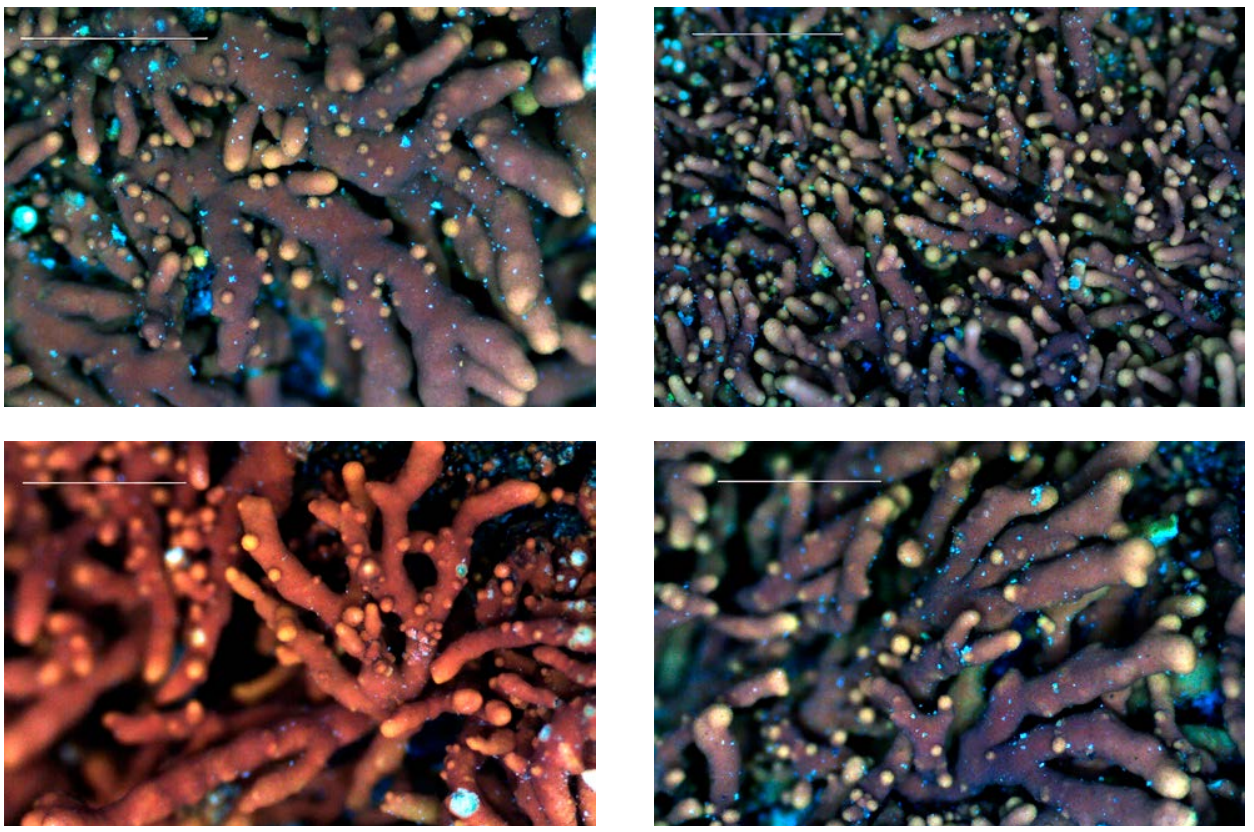

Fig. 6. Hosseusiella pergracilis (CL130397), enlarged portions of thalline lobes with isidia in peripheral (top) and central portion of thallus (bottom). Scale $1 \mathrm{~mm}$ 
The genus Follmannia C. W. Dodge was resurrected by Arup et al. (2013) based on phylogenetic analyses of nrITS and nrLSU sequences, using a single specimen.

Additional ITS-sequences for Follmannia orthoclada are included in this study.

Specimens of Follmannia orthoclada examined: Chile, Cuesta Buenos ayres, on rock. Lat.: $29^{\circ} 35^{\prime} 11.7^{\prime \prime}$ S; Long.: 71 ${ }^{\circ} 14^{\prime}$ 52.9" W; Alt.: ca. $257 \mathrm{~m}$ a.s.l. Coll.: Oh, S.-O., Hur, J.-S., 13.11.2013 [site 04] (CL130409) (KoLRI 020543 voucher for DNA SK H94 = J76). - Chile,

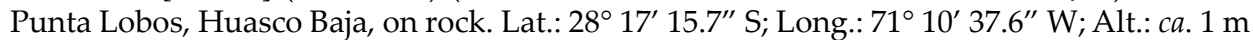
a.s.l. Coll.: Oh, S.-O., Hur, J.-S., 14.11.2013 [site 04] (CL130466) (KoLRI 020602 voucher for DNA SK i00 = J78).

Rehmanniella S. Y. Kondr. et J.-S. Hur, gen. nov.

MycoBank no.: MB 824013.

Similar to Neobrownliella, but differs in having larger, convex areoles with numerous sessile apothecia with a well-developed proper margin, and a well-developed epinecral layer on the outer side of the proper margin.

Type species: Rehmanniella wirthii S. Y. Kondr.

Thallus crustose, areolate or continuous, initially thin, becoming thicker, grey or yellow grey, indistinct and hardly differentiated from the substrate, with numerous rusty, reddish orange biatorine apothecia.

Apothecia $0.2-0.7 \mathrm{~mm}$ diam., biatorine, immersed, becoming sessile; proper margin dull orange, dull yellowish orange to dark orange or reddish orange, with whitish pruina on outer side; disc plane, from dull reddish orange to pinkish orange, with yellowish pruina, 5-13 aggregated per areole; in section biatorine, true exciple dull orange or orange-brown in outermost layer of the lateral portion and a hyaline inner portion, a hyaline epinecral layer rich on crystals, the basal portion Blastenia-type; algal zone absent in apothecia; paraphyses without swellings towards the tips, richly branched in the upper portion; subhymenium hyaline, with oil droplets; asci 8-spored, mature ascospores rather rare, narrowly ellipsoid, fusiform to almost cylindrical, rather small and with narrow septa. Conidiomata frequent, appearing like small apothecia, dull orange, mature conidia not observed.

Spot tests: Epihymenium and outermost portion of true exciple $\mathrm{K}+$ purple.

Ecology: It grows on siliceous rocks.

Etymology: Rehmanniella is named after the Polish geographer, geomorphologist, botanist and explorer Anton Rehmann (1840-1917), who was one of the first collectors of bryophytes and vascular plants in South Africa, during the periods 1875-1877 and 1879-1880. Rehmann published in German and 
is regarded as an Austrian botanist. Lviv in Galicia (now Ukraine), where he lived, was then a part of the Austro-Hungarian Empire (as Lemberg).

Distribution: Known only from the type locality in South Africa.

Taxonomic notes: Rehmanniella is similar to species of Neobrownliella, but differs in having rather large, to $1.5 \mathrm{~mm}$ broad areoles with numerous and aggregated, sessile apothecia with a well-developed, pronounced proper margin with a distinct epinecral layer on the outer side of the proper margin, as well as in its position in the Sirenophila-Lazarenkoiopsis clade of the Teloschistoideae.

With whitish pruina on the outer side of proper margin of the biatorine apothecia, Rehmanniella wirthii resembles the Australian "Caloplaca" johnwhinrayi S. Y. Kondr. et Kärnefelt, but differs in having biatorine apothecia, in shorter ascospores, and in narrower ascospore septum, as well as in its ecology and in its distribution.

The gene phylogeny of Rehmanniella suggested a relationship with the Northern Hemisphere Lazarenkoiopsis. However, the support of this branch was extremely low (51-55), while separate monophyletic branches of the Rehmanniella and Lazarenkoiopsis have high levels of bootstrap support.

\section{Rehmanniella wirthii S. Y. Kondr., spec. nova} (Fig. 7)

MycoBank no.: MB 824014.

Similar to Neobrownliella montisfracti, but differs in having a grey to whitish grey thallus, where the areoles become much thicker and semiconvex in the centre of thallus; in having sessile apothecia, in having a well-developed epinecral layer on the outer side of the proper margin, in having numerous apothecia, often 5-13 per areole, in having longer ascospores, and an African distribution.

Type: South West Africa, Namibia, distr. Omaruru, Central Namib Desert: Myl72, Languberg, SW vom Gipfel. Lat.: 21 49' 43.3" S; Long.: 14 04' 58.6”' E; Alt.: ca. $130 \mathrm{~m}$ a.s.1. Coll.: Wirth, V. and Heklau, M., 14.05.2002. (STU - holotype, for DNA SK243 and SK244).

Thallus crustose, 1-2 cm wide, grey or dirty whitish grey, hardly differentiated from the substrate, areolate or continuous, thin and flat, becoming thick and uneven with irregularly swollen central portion; upper surface uneven and dusty, mostly distinct because of aggregated dull, rusty reddish orange biatorine apothecia, in contrast to the thallus. Areoles $0.5-1 \mathrm{~mm}$ wide, initially thin and flat, becoming thicker to $1-1.5 \mathrm{~mm}$ wide, with several apothecia. Thalline areoles 70-90(-100) $\mu \mathrm{m}$ thick in section, with numerous crys- 
tals, insoluble in $\mathrm{K}, 15-25(-35) \mu \mathrm{m}$ wide, with numerous air bubbles; algal cells (12-)15-20(-22) $\mu$ m wide.

Apothecia 0.2-0.7 mm diam., biatorine, immersed, becoming sessile, not constricted at base; proper margin $0.3-0.5 \mathrm{~mm}$ wide, dull orange, dull yellowish orange to dark orange or reddish orange, pinkish orange, often with a whitish pruina on the outermost lower lateral portion; disc plane, reddish orange to pinkish orange, yellowish pruina, aggregated, often 5-13 per areole; in section biatorine, true exciple $40-50 \mu \mathrm{m}$ thick in the uppermost lateral por-
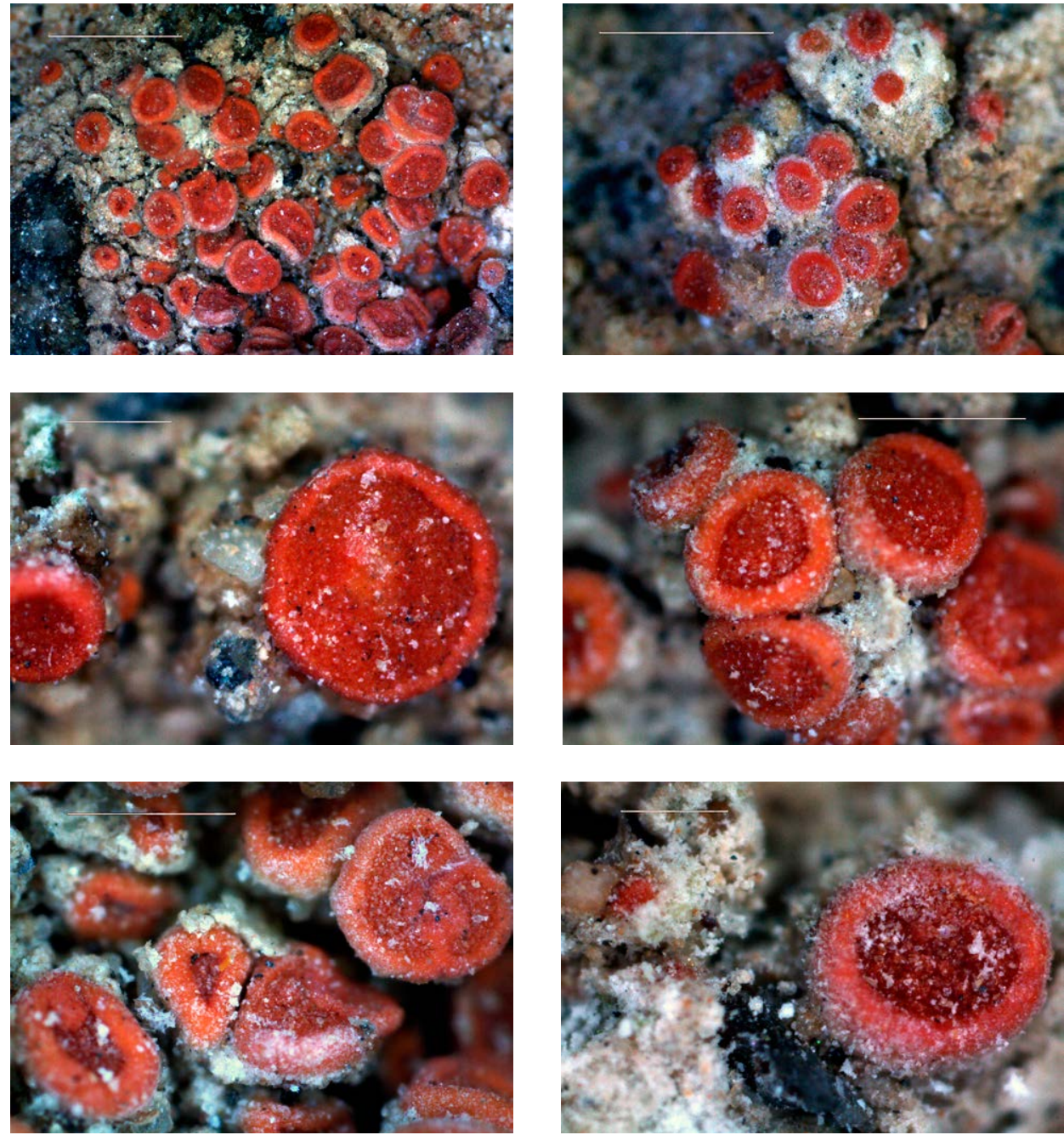

Fig. 7. Rehmanniella wirthii (holotype), general habit (top and centre, scale $1 \mathrm{~mm}$ ), and enlarged apothecia (bottom, scale $0.5 \mathrm{~mm}$ ) 
tion, distinctly raised above the level of the disc, $60-70 \mu \mathrm{m}$ wide in the lower lateral portion, outermost layer of lateral portion of true exciple 10-15(-20) $\mu \mathrm{m}$ thick, dull orange or orange-brownish, inner portion $25-35 \mu \mathrm{m}$ wide, hyaline, supplied with a hyaline, 10-15(-50) $\mu \mathrm{m}$ thick, epinecral layer, broadening in the outer lower portion, rich on the crystals, (10-)15-20(-40) $\mu \mathrm{m}$ across; in basal portion to $20 \mu \mathrm{m}$ thick, more or less of the Blastenia-type (Kondratyuk et al. 2014), 50(-90) $\mu \mathrm{m}$ thick, hyaline; algal zone absent in apothecia, thalline algal layer continuous below apothecia; hymenium 60-75 $\mu \mathrm{m}$ high; paraphyses not swollen towards the tips, 3-4(-5.5) $\mu \mathrm{m}$ diam., richly branched in the upper portion; subhymenium (30-)40-70(-80) $\mu \mathrm{m}$ thick, hyaline, with rare oil droplets, 3-4 $\mu \mathrm{m}$ diam.; asci 8-spored, ascospores poorly developed, bipolar ascospores rare, narrowly ellipsoid, fusiform to almost cylindrical 10-12(-14) $\times(4.2-) 4.5-5.5 \mu \mathrm{m}$ in water and (9-)11-13(-14) $\times(4.5-) 5-6.5 \mu \mathrm{m}$ in $\mathrm{K}$ with attenuated ends; ascospore septum narrow (1-)1.5-2(-3) $\mu \mathrm{m}$ wide in water and (1-)1.5-2(-3) $\mu \mathrm{m}$ thick in $\mathrm{K}$.

Conidiomata frequent, with similar shape to small apothecia, dull orange, mature conidia not observed.

Spot tests: Epihymenium and outermost portion of true exciple K+ purple.

Ecology: Growing on siliceous rocks along cracks in rock surface in somewhat dusty portions, often associated with Caloplaca cf. wesselsii S. Y. Kondr. et V. Wirth (see also Wirth and Kondratyuk 2010).

Etymology: The species epithet in honour of Volkmar Wirth, who supplied us with the collections of this species.

Distribution: Known from the type locality in the Namib Desert.

Taxonomic notes: Rehmanniella wirthii is similar to the Australian species Neobrownliella montisfracti (S. Y. Kondr., Elix et Kärnefelt) S. Y. Kondr., Elix, Kärnefelt et A. Thell. Both species have a grey or dirty whitish grey crustose thallus and reddish orange or pinkish orange biatorine apothecia, and grow on siliceous rocks, however $N$. montisfracti differs from $R$. wirthii in having immersed apothecia, shorter ascospores, 7-11 $\mu \mathrm{m}$ long, slightly broader septa, 1.5-3 $\mu \mathrm{m}$ wide, and in distribution (Kantvilas 2016).

The Australian species "Caloplaca" johnwhinrayi S. Y. Kondr. et Kärnefelt is morphologically similar, but differs in having zeorine apothecia, the presence of oil droplets in the paraphyses and longer ascospores $(12-15 \mu \mathrm{m})$, with broader septa $(3-6 \mu \mathrm{m})$. Furthermore, "C." johnwhinrayi prefers limestone as substrate (Kantvilas 2016).

\section{New combination}

The combined phylogenetic analysis based on ITS nrDNA, $28 \mathrm{~S}$ nrLSU, and $12 \mathrm{~S} \mathrm{mtSSU}$ sequences shows that the recently described Sirenophila ovis- 
atra (Søchting et al. 2016) is better positioned in the genus Elixjohnia and a new combination is proposed here. The species grows on maritime rocks in the Verrucaria zone in southern Patagonia, the Falkland Islands and Macquarie Island, often as a parasite on members of the genus Hydropunctaria.

Elixjohnia ovis-atra (Søchting, Søgaard et Sancho) S. Y. Kondr., comb. nova - MycoBank no.: MB 824015 - Basionym: Sirenophila ovis-atra Søchting, Søgaard et Sancho, in Søchting et al., Opuscula Philolichenum 15(2): 2 (2016).

Acknowledgements - We thank Dr Edit Farkas and Dr J. A. Elix for valuable comments on manuscript, Prof. Dr Volkmar Wirth for collections. The project was supported by the Ministry of Education and Science of Ukraine (M/90-2015-285 and M/34-2016-285) and by Korean Brain Pool Program (161S-4-3-1659) for SK, and the Korea National Research Resource Centre Program, the Korean Forest Service Program (KNA 2012-2016) through the Korea National Arboretum for JSH, and also the Hungarian Scientific Research Fund (OTKA K81232) for LL, and the Almborn Foundation (Lund, Sweden) for AT.

\section{REFERENCES}

Arup, U., Søchting, U. and Frödén, P. (2013): A new taxonomy of the family Teloschistaceae. - Nord. J. Bot. 31(1): 16-83. https://doi.org/10.1111/j.1756-1051.2013.00062.x

Ekman, S. (1999): PCR optimization and troubleshooting, with special reference to the amplification of ribosomal DNA in lichenized fungi. - Lichenologist 31(5): 517-531. https://doi.org/10.1017/s0024282999000675

Fedorenko, N. M., Stenroos, S., Thell, A., Kärnefelt, I. and Kondratyuk, S. Y. (2009): A phylogenetic analysis of xanthorioid lichens (Teloschistaceae, Ascomycota) based on ITS and mtSSU sequences. - Bibl. Lichenol. 100: 49-84.

Fedorenko, N. M., Stenroos, S., Thell, A., Kärnefelt, I., Elix, J. A., Hur, J. S. and Kondratyuk, S. Y. (2012): Molecular phylogeny of xanthorioid lichens (Teloschistaceae, Ascomycota), with notes on their morphology. - Bibl. Lichenol. 108: 45-64.

Gardes, M. and Bruns, T. D. (1993): ITS primers with enhanced specificity for basidiomycetes - application to the identification of mycorrhizae and rusts. - Mol. Ecol. 2: 113118. https://doi.org/10.1111/j.1365-294x.1993.tb00005.x

Gaya, E., Navarro-Rosinés, P., Llimona, X., Hladun, N. and Lutzoni, F. (2008): Phylogenetic reassessment of the Teloschistaceae (lichen-forming Ascomycota, Lecanoromycetes). - Mycol. Res. 112: 528-546. https://doi.org/10.1016/j.mycres.2007.11.005

Gaya, E., Högnabba, F., Holguin, Á., Molnár, K., Fernández-Brime, S., Stenroos, S., Arup, U., Søchting, U., van den Boom, P., Lücking, R., Sipman, H. J. M. and Lutzoni, F. (2012): Implementing a cumulative supermatrix approach for a comprehensive phylogenetic study of the Teloschistales (Pezizomycotina, Ascomycota). - Mol. Phyl. Evol. 63: 374-387. https://doi.org/10.1016/j.ympev.2012.01.012

Gaya, E., Fernández-Brime, S., Vargas, R., Lachlan, R. F., Gueidan, C., Ramírez-Mejía, M. and Lutzoni, F. (2015): The adaptive radiation of lichen-forming Teloschistaceae is associated with sunscreening pigments and a bark-to-rock substrate shift. - Proc. Natl Acad. Sci. USA 112(37): 11600-11605. https://doi.org/10.1073/pnas.1507072112 
Kantvilas, G. (2016): A synopsis and key for the lichen genus Caloplaca (Teloschistaceae) on Kangaroo Island, with the description of two new species. - J. Adelaide Bot. Gardens 29(6): 53-69.

Kärnefelt, I., Kondratyuk, S., Søchting, U., Frödén, P. and Arup, U. (2002): Two new species of Caloplaca (Teloschistaceae) from the Southern Hemisphere. - Bryologist 105(3): 301-309. https://doi.org/10.1639/0007-2745(2002)105[0301:tnsoct]2.0.co;2

Kondratyuk, S. and Kärnefelt, I. (1997): Josefpoeltia and Xanthomendoza, two new genera in the Teloschistaceae (lichenized Ascomycotina). - Bibl. Lichenol. 68: 19-44.

Kondratyuk, S. (2004): Oxneria, Rusavskia, Teloschistes, Xanthoanaptychia, Xanthomendoza, Xanthoria. - In: Andreev, M. P. and Roms, E. G. (eds): Handbook of the lichens of Russia. 9. Fuscideaceae, Teloschistaceae. Nauka, Sankt-Peterburg, pp. 242-323.

Kondratyuk, S., Jeong, M.-H., Yu, N.-H., Kärnefelt, I., Thell, A., Elix, J. A., Kim, J., Kondratiuk, A. S. and Hur, J.-S. (2013): Four new genera of teloschistoid lichens (Teloschistaceae, Ascomycota) based on molecular phylogeny. - Acta Bot. Hung. 55(3-4): 251-274. https://doi.org/10.1556/abot.55.2013.3-4.8

Kondratyuk, S. Y., Jeong, M.-H., Yu, N.-N., Kärnefelt, I., Thell, A., Elix, J. A., Kim, J., Kondratiuk, A. S. and Hur, J.-S. (2014): A revised taxonomy for the subfamily Caloplacoideae (Teloschistaceae, Ascomycota) based on molecular phylogeny. - Acta Bot. Hung. 56: 93-123. https://doi.org/10.1556/abot.56.2014.1-2.12

Kondratyuk, S., Kärnefelt, I., Thell, A., Elix, J. A., Kim, J., Kondratiuk, A. S. and Hur, J.-S. (2015a): Tassiloa, a new genus in the Teloschistaceae (lichenized ascomycetes). - Graphis Scripta 27(1-2): 22-26.

Kondratyuk, S. Y., Kärnefelt, I., Thell, A., Elix, J. A., Kim, J., Kondratiuk, A. S. and Hur, J.-S. (2015b): Brownlielloideae, a new subfamily in the Teloschistaceae (Lecanoromycetes, Ascomycota). - Acta Bot.Hung. 57(3-4):321-343. https://doi.org/10.1556/034.57.2015.34.6

Kondratyuk, S. Y., Kim, J. A., Yu, N.-H., Jeong, M.-H., Jang, S. H., Kondratiuk, A. S., Zarei-Darki, B. and Hur, J.-S. (2015c): Zeroviella, a new genus of xanthorioid lichens (Teloschistaceae, Ascomycota) proved by three gene phylogeny. - Ukr. Bot. J. 72(6): 574-584. https://doi.org/10.15407/ukrbotj72.06.574

Kondratyuk, S. Y., Lőkös, L., Upreti, D. K., Nayaka, S., Mishra, G. K., Ravera, S., Jeong, M.-H., Jang, S.-H., Park, J. S. and Hur, J.-S. (2017): New monophyletic branches of the Teloschistaceae (lichen-forming Ascomycota) proved by three gene phylogeny. Acta Bot. Hung. 59(1-2): 71-136. https://doi.org/10.1556/034.59.2017.1-2.6

Lumbsch, H. T., Ahti, T., Altermann, S., Amo de Paz, G., Aptroot, A., Arup, U., Bárcenas Peña, A., Bawingan, P. A., Benatti, M. N., Betancourt, L., Björk, C. R., Boonpragob, K., Brand., M., Bungartz, F., Cáceres, M. E. S., Candan, M., Chaves, J. L., Clerc, P., Common, R., Coppins, B. J., Crespo, A., Dal-Forno, M., Divakar, P. K., Duya, M. V., Elix, J. A., Elvebakk, A., Fankhauser, J. D., Farkas, E., Itati-Ferraro, L., Fischer, E., Galloway, D. J., Gaya, E., Giralt, M., Goward, T., Grube, M., Hafellner, J., Hernández, J. E., Herrera Campos, M. A., Kalb, K., Kärnefelt, I., Kantvilas, G., Killmann, D., Kirika, P., Knudsen, K., Komposch, H., Kondratyuk, S., Lawrey, J. D., Mangold, A., Marcelli, M. P., McCune, B., Messuti, M. I., Michlig, A., González, R. M., Moncada, B., Naikatini, A., Nelsen, M. P., Øvstedal, D. O., Palice, Z., Papong, K., Parnmen, S., Pérez-Ortega, S., Printzen, C., Rico, V. J., Rivas Plata, E., Robayo, J., Rosabal, D., Ruprecht, U., Salazar Allen, N., Sancho, L., Santos de Jesus, L., Santos Vieira, T., Schultz, M., Seaward, M. R. D., Sèrusiaux, E., Schmitt, I., Sipman, H. J. M., Sohrabi, M., Søchting, U., Søgaard, M. Z., Sparrius, L. B., Spielmann, A., Spribille, T., Sutjaritturakan, 
J., Thammathaworn, A., Thell, A., Thor, G., Thüs, H., Timdal, E., Truong, C., Türk, R., Umaña Tenorio, L., Upreti, D. K., van den Boom, P., Vivas Rebuelta, M., Wedin, M., Will-Wolf, S., Wirth, V., Wirtz, N., Yahr, R., Yeshitela, K., Ziemmeck, F., Wheeler, T. and Lücking, R. (2011): One hundred new species of lichenized fungi: a signature of undiscovered global diversity. - Phytotaxa 18: 1-137.

Malme, G. O. A. (1926): Lichenes blasteniospori Herbarii Regnelliani. - Ark. Bot. 20A(9): $1-51$.

Park, S.-Y., Jang, S.-H., Oh, S.-O., Kim, J. A. and Hur, J.-S. (2014): An easy, rapid, and costeffective method for DNA extraction from various lichen taxa and specimens suitable for analysis of fungal and algal strains. - Mycobiology 42(4): 311-316. https://doi. org/10.5941/myco.2014.42.4.311

Søchting, U., Sogaard, M. Z., Elix, J. A., Arup, U., Elvebakk, A. and Sancho, L. G. (2014): Catenarina (Teloschistaceae, Ascomycota), a new Southern Hemisphere genus with 7-chlorocatenarin. - Lichenologist 46(2): 175-187. https://doi.org/10.1017/ s002428291300087x

Søchting, U., Søgaard, M. Z., Sancho, L. G., Fröden, P. and Arup, U. (2016): Sirenophila ovis-atra a new species of maritime Teloschistaceae from the Southern Hemisphere. - Opuscula Philolichenum 15(2): 1-5.

Swofford, D. L. (2003): PAUP*, Phylogenetic analysis using parsimony (*and other methods). Sunderland, Sinauer Associates, Massachusetts.

Tamura, K., Peterson, D., Peterson, N., Stecher, G., Nei, M. and Kumar, S. (2011): MEGA5: molecular evolutionary genetics analysis using maximum likelihood, evolutionary distance, and maximum parsimony methods. - Mol. Biol. Evol. 28: 2731-2739. https:// doi.org/10.1093/molbev/msr121

Vilgalys, R. and Hester, M. (1990): Rapid genetic identification and mapping of enzymatically amplified ribosomal DNA from several Cryptococcus species. - J. Bacteriol. 172(8): 4238-4246. https://doi.org/10.1128/jb.172.8.4238-4246.1990

Vondrák, J., Khodosovtsev, A., Šoun, J. and Vondráková, O. (2012): Two new European species from the heterogeneous Caloplaca holocarpa group (Teloschistaceae). - Lichenologist 44(1): 73-89. https://doi.org/10.1017/s0024282911000636

White, T. J., Bruns, T., Lee, S. and Taylor, J. (1990): Amplification and direct sequencing of fungal ribosomal RNA genes for phylogenetics. - PCR Protocols 38: 315-322. https:// doi.org/10.1016/b978-0-12-372180-8.50042-1

Wirth, V. and Kondratyuk, S. Y. (2010): Neue Arten der Flechtenfamilie Teloschistaceae aus der Manibwuste und der Sukkulenten-Karoo (SW Afrika). - Herzogia 23(2): 1-16.

Zahlbruckner, A. (1925): Chilenische Flechten. - Meddel. Göteborgs Bot. Trädgard 2: 1-26. 